\title{
Labor Migration from Kruševo: Mobility, Ottoman Transformation, and the Balkan Highlands in the 19th Century
}

\author{
Akın Sefer* (D), Aysel Yıldız and Mustafa Erdem Kabadayı \\ UrbanOccupationsOETR, History Department, Koç University, Istanbul, 34450 Turkey \\ ${ }^{*}$ Corresponding author. aksefer@ku.edu.tr
}

\begin{abstract}
Although mountainous regions remained relatively isolated and almost untouched by the Ottoman rule, labor migration connected the inhabitants of these regions to the socioeconomic and political processes in the Ottoman Empire and beyond. Kruševo, a highland village located in present-day North Macedonia, provides an excellent case for understanding these connections. This paper presents systematic evidence from the Ottoman archives to document and analyze the social, economic, and demographic impacts of labor migration during this period. It provides an in-depth analysis of the Ottoman population and tax records of Kruševo in the 1840 s, demonstrating the occupational profiles, migration patterns, and family and neighborhood networks of village residents during this period. Based on this analysis, it argues that labor migration was key to the transformation of social, economic, and demographic relations in rural communities and to the integration of even the most remote highland villages with the modernization processes that characterized the Ottoman Empire in the 19th century.
\end{abstract}

Keywords: 19th century; Kruševo; labor migration; modernization; the Ottoman Balkans

There was no ostensible reason for the Austrian Consul-General, J. G. von Hahn, to prolong his trip from Belgrade to Salonica in 1858-59 for the sake of visiting a mountainous village called Kruševo, part of the kaza (administrative division) of Manastır (Bitola) in Ottoman Rumelia. The goal of his larger trip was to explore the territory for potential railway lines to be constructed in the southern Balkans, and Kruševo, reached after six hours on a swampy road from Prilep, would not appear worthy in this regard. Still, he noted, "this town, not listed by any known map, drove our attention to a high degree." Indeed, the place he visited was remarkably identical to an urban town, with hundreds of craftsmen in several artisanal and commercial shops, with an ethnically heterogeneous population speaking various languages and dialects, commercial networks to cities from Salonica to Vienna, and a landscape marked by churches, inns, schools, and stone houses. To his great surprise, this village, which was inhabited by "at least 7000 people" and located at the "gates of the civil and military capital of Rumelia," that is, the city of Bitola, remained unnoticed and unexplored by cartographers. ${ }^{1}$

Kruševo, today located in North Macedonia and known as the highest town in the Balkans, with an altitude of around 1,350 meters, was indeed able to defy its geographical distance from commercial hubs in the region thanks to the mobility of its people, which was central to its ability to sustain such a remarkably large and diverse population and to its social and economic transformation in the 19th century. Known as pečalbarstvo (in Slavic) or gurbet (in Turkish) throughout the Balkans, the mobility of labor migrants who maintained ties to their homelands regardless of how long they worked in the place of destination, has already been acknowledged as a defining phenomenon of life in the rural Balkans by

\footnotetext{
${ }^{1}$ J. G. von Hahn, Reise von Belgrad nach Salonik: Nebst vier Abhandlungen zur alten Geschichte des Morawagebietes (Vienna: Verlag von Tendler, 1868), 180-83.

(c) The Author(s), 2021. Published by Cambridge University Press. This is an Open Access article, distributed under the terms of the Creative Commons Attribution licence (http://creativecommons.org/licenses/by/4.0/), which permits unrestricted re-use, distribution, and reproduction in any medium, provided the original work is properly cited.
} 
historians. ${ }^{2}$ Such mobility was not limited to the Balkans, and Ottoman historians have put an increasing emphasis on the ways migration and mobility characterized imperial, trans-regional, and trans-imperial experiences and processes throughout Ottoman history. ${ }^{3}$

Since mass migrations characterized demographic transformations especially in the last century of Ottoman history, it is not surprising that studies of migration have tended to focus on massive flows of immigration to and emigration from the Ottoman Empire in this period. ${ }^{4}$ However, the nascent literature on labor migration has demonstrated that mobility in Ottoman society might have had a more permanent and widespread character than the massive population movements otherwise suggest. Indeed, beginning in earlier centuries and increasingly in the 19th century, people in different parts of the empire traveled in seasonal or circular patterns, from rural to urban areas or across different urban or agricultural settlements within the empire, to work or to find employment. ${ }^{5}$

In spite of its significance, however, labor migration has remained marginal to Ottoman historiography. This has been the case particularly for the period prior to the late 19th century, as even historians of labor migration tend to focus primarily on the last decades of the empire. The main reasons for this have been the challenges of documenting the scope and tracing the mobility of working people for earlier periods in Ottoman history, especially when this mobility did not take place on massive scales within a limited period, which would have produced abundant official and unofficial written records, as demonstrated by the above-cited works on Armenian and Arab emigration from the Ottoman Empire. Besides, studies on labor migration largely focus on the experiences of migrants and the impact of their mobility on towns and cities. ${ }^{6}$ The dramatic impacts of outward migration, particularly on the rural communities that

\footnotetext{
${ }^{2}$ See, for example, Traian Stoianovich, "The Conquering Balkan Orthodox Merchant," Journal of Economic History 20, no. 2 (1960): 234-313; Michael Palairet "The Migrant Workers of the Balkans and Their Villages (18th Century-World War II)," in Handwerk in Mittel- und Südosteuropa. Mobilität, Vermittlung und Wandel im Handwerk des 18. bis 20. Jahrhunderts, ed. Klaus Roth (Munich: Südosteuropa-Gesellschaft, 1987), 23-46; Keith Brown, "From the Balkans to Baghdad (via Baltimore): Labor Migration and the Routes of Empire," Slavic Review 69, no. 4 (2010): 816-34; and Petko Hristov, "The Balkan Gurbet: Traditional Patterns and New Trends," in Migration in the Southern Balkans: From Ottoman Territory to Globalized Nation States, ed. Hans Vermeulen et al. (Cham, Switzerland: Springer, 2015), 31-46.

${ }^{3}$ Reşat Kasaba, A Moveable Empire: Ottoman Nomads, Migrants, and Refugees (Seattle: University of Washington Press, 2011); Suraiya Faroqhi, Travel and Artisans in the Ottoman Empire: Employment and Mobility in the Early Modern Era (London: I. B. Tauris, 2014); Stacy D. Fahrenthold, “Arab Labor Migration in the Americas, 1880-1930," in Oxford Research Encyclopedia of American History (Oxford, UK: Oxford University Press, 2019); Florian Riedler and Stefan Rohdewald, "Migration and Mobility in a Transottoman Context," Radovi 51, no. 1 (2019): 201-19.

${ }^{4}$ For recent works along this line see Akram Fouad Khater, Inventing Home: Emigration, Gender, and the Middle Class in Lebanon, 1870-1920 (Berkeley, CA: University of California Press, 2001); Isa Blumi, Ottoman Refugees, 1878-1939: Migration in a Post-Imperial World (London: Bloomsbury, 2013); Stacy D. Fahrenthold, Between the Ottomans and the Entente: The First World War in the Syrian and Lebanese Diaspora, 1908-1925 (New York: Oxford University Press, 2019); and David Gutman, The Politics of Armenian Migration to North America, 1885-1915: Sojourners, Smugglers and Dubious Citizens (Edinburgh: Edinburgh University Press, 2019).

${ }^{5}$ Reşat Kasaba, "Migrant Labor in Western Anatolia, 1750-1850," in Landholding and Commercial Agriculture in the Middle East, ed. Çağlar Keyder and Faruk Tabak (Albany, NY: State University of New York Press, 1991), 113-21; Christopher Clay, "Labour Migration and Economic Conditions in Nineteenth-Century Anatolia," Middle Eastern Studies, 34 no. 4 (1998): 132; Eyal Ginio, "Migrants and Unskilled Local Workers in an Ottoman Port City: Ottoman Salonica in the Eighteenth-Century," in Outside In: On the Margins of the Modern Middle East, ed. Eugene L. Rogan (London: I. B. Tauris, 2002), 126-48; M. Erdem Kabadayl, "Mobility and Resistance in the Light of Ottoman Settlement Policies in the Second Half of the Nineteenth Century: The Transfer of Agricultural Labourers from Syria to Dobrudja," in Ottoman Rural Societies, ed. Mohammad Afifi et al. (Cairo: IFAO, 2005), 225-40; Ișık Tamdoğan, "La mobilité comme compétence de la société ottomane. Nomades de la Çukurova et travailleurs migrants à Üsküdar au XVIIIe siècle," in Le monde de l'itinérance en Méditerranée de l'Antiquité à l'époque moderne: Procédures de contrôle et d'identification, ed. Claudia Moatti, Wolfgang Kaiser, and Christophe Pébarthe (Bordeaux: Ausonius, 2009), 181-99; Florian Riedler, "The Role of Labour Migration in the Urban Economy and Governance of Nineteenth-Century Istanbul," in Urban Governance under the Ottomans: Between Cosmopolitanism and Conflict, ed. Ulrike Freitag and Nora Lafi (London: Routledge, 2014), 157-70; İrfan Kokdaş, "Manisa'da Çiftlik, Ağıl ve Mandıralardaki Tarımsal İşgücü Profili: Emek Hareketliliği ve Sosyo-Hukuki Dönüşümler, 1690-1870,” Meltem İzmir Akdeniz Akademisi Dergisi, no. 3 (2018): 42-55; Irfan Kokdaş and Yahya Araz, "İstanbul'da Ev İçi Hizmetlerinde İstihdâm Edilen Kuzeybatı Anadolulu Kız Çocuklarının Göç Ağları Üzerine Bir Değerlendirme (1845-1911),” Tarih İncelemeleri Dergisi 33, no. 1 (2018): 41-68.
}

${ }^{6}$ See Ulrike Freitag et al., eds., The City in the Ottoman Empire: Migration and the Making of Ottoman Modernity (New York: Routledge, 2011). 
migrants left behind, are equally important to understanding the socioeconomic transformations of late Ottoman society. ${ }^{7}$

For the era before the late 19th century, when such records were scarce, systematic collection and a comprehensive analysis of quantitative data is necessary to understand the dynamics of overall labor migration, due to its sporadic character across place and time. Although perhaps the most widespread form of human mobility in the empire, the characteristics of this phenomenon were not well understood, as most archival documents did not refer to labor migrants as a distinct group or population unit. This made it difficult to trace them and to comprehend the impact of their mobility on macro-historical processes. The data below show that a systematic analysis of the Ottoman population and tax records can reveal a lot to fill this gap and make labor migrants and migration more visible in the historiography. Qualitative records on labor migrants, particularly for the era prior to the late 19th century, are not abundant, and data collection from these quantitative records allows introduction of these people and their mobility into the larger debates about Ottoman and Middle Eastern history.

This article utilizes data compiled from the population and tax registers of mid-19th-century Kruševo that have recently become available to researchers. ${ }^{8}$ Ottoman population registers have become popular sources for preliminary, and unfortunately limited and descriptive, studies on Ottoman demography. Nevertheless, joint use of mid-19th-century Ottoman surveys bears hitherto almost unused potentials. The cross-utilization of population and tax registers through manual matching widens our perspective on individuals registered by multiple sources. ${ }^{9}$ In this article, we will use population and poll-tax (cizye) registers mostly in combination, obtaining a larger perspective with additional information extracted from the temettuat (income yielding assets) registers. Rather than a selective and sporadic use of these registers focusing on individuals or households as the unit of analysis, we will operate on a wide scale to study Kruševo by making use of registers concerning poll-tax, temettuat, and population in the mid-19th century. ${ }^{10}$

A comprehensive analysis of these registers shows that labor migration is central to analyzing the diversity of socioeconomic identities and experiences of rural communities in the Balkans. An in-depth focus on labor migration is key to understanding how highland communities, even in the absence of modern transportation networks, could become integrated with the imperial transformation processes that characterized the 19th-century Ottoman Empire. The case of Kruševo allows us to see labor migration as decisive in the social and economic transformation of highland villages within the context of imperial-level transformations in this period, and the ways people in these villages could participate in some of the Ottoman reform processes concerning socioeconomic relations in rural areas. Thanks to their mobility and networks, villagers of Kruševo played an active role in reproduction of some of the imperial transformations at the local level, becoming part of the larger narrative of Ottoman modernization in the 19th century.

The example of Kruševo proves that migration networks and patterns were critical in Ottoman socioeconomic transformation in the 19th century, as labor migrants were at the heart of demographic, cultural, spatial, and economic changes in this period. It was by means of their mobility and networks that this highland community not only underwent demographic, economic, and spatial transformations, but also was

\footnotetext{
${ }^{7}$ See Janeen Arnold Costa, "The History of Migration and Political Economy in Rural Greece: A Case Study," Journal of Modern Greek Studies 6, no. 2 (1988): 159-85; Akram Fouad Khater, “House' to 'Goddess of the House': Gender, Class, and Silk in 19th-Century Mount Lebanon," International Journal of Middle East Studies 28, no. 3 (1996): 325-48; and Violetta Hionidou, "They Used to Go and Come': A Century of Circular Migration from a Greek Island, Mykonos, 1850 to 1950 ," Annales de Démographie Historique 2, no. 104 (2002): 51-77.

${ }^{8}$ Mid-19th-century Ottoman population registers (NFS. d. series) were made accessible in 2011 at the Ottoman state archives in Istanbul (Presidency State Archives of the Republic of Turkey, hereafter BOA). Although tax registers from the same period (ML.VRD.TMT temettuat series) were opened for research in the 1990s, and numerous temettuat registers were included in the Kamil Kepeci (KK) collection much earlier, we still lack systematic and comprehensive historical analyses based on these tax registers.

${ }^{9}$ For a good example of such a cross use of Ottoman temettuat and population registers to compare and contrast economic and demographic information for chosen individuals in an urban setting, see Dilek Akyalçın Kaya, “'Living off Others' Aid': The Socioeconomic Structure of Salonica's Jews in the Mid-Nineteenth Century,” Jewish History, 28, no. 3-4 (2014): 313-36.

${ }^{10}$ It is beyond individual efforts to read, transcribe, and extract economic and demographic information from three different types of surveys covering only one location of this size without dedicating enormous time. We are lucky to be part of a large research group (UrbanOccupationsOETR), which curated sources, extracted data, and created a relational digital data set.
} 
able to wage a persistent struggle against landowners over property, leading them to actively engage with the Ottoman reform process concerning rural transformation, and in particular property relations, led by the Tanzimat bureaucracy. This allows us to highlight the impacts of labor migration on land struggles and rural transformation in the 19th century, a dimension that has received little scholarly attention to date. ${ }^{11}$

Following a discussion of the connections between migration and the 19th-century transformation processes in the Ottoman Empire, we will introduce the history of Kruševo, with a focus on the role and characteristics of migration in the making of this community. We will then describe the occupational structure, migration patterns, and migrant networks based on data extracted from the mid-19th-century Ottoman population and tax registers. We also will discuss how migrants continued to preserve their connections with the village, in some cases despite long years of absence. Finally, we will consider struggles between landlords and villagers during this period to gain an understanding of the critical role of migration in the transformation of Kruševo in the 19th century.

\section{Migration and Demographic Transformation in Kruševo}

An old settlement dating back at least to the 15th century, the village of Kruševo consisted of around forty to forty-five houses until the mid-18th century. ${ }^{12}$ The population gradually increased as immigrants settled in the village throughout the next decades. Particularly after the prosperous Vlach town of Moscopole was sacked and destroyed twice, in 1769 and 1788, Kruševo attracted considerable waves of Vlach immigrants. ${ }^{13}$ Migration into the village continued in at least two more waves in the early 19th century, this time consisting largely of Mijaks. ${ }^{14}$ As a result of these migration waves, by the mid-19th century Kruševo had developed into a town-like village with thirteen quarters, consisting exclusively of Christians speaking different languages and dialects (Fig. 1).

When the central bureaucracy of the Ottoman Empire launched a large-scale modernization program known as the Tanzimat in the mid-19th century, one of the first products of this process was a series of population registers that sought to cover most, if not all, territories of the empire. ${ }^{15}$ The goals of registration were to determine the number of taxpayers, to help with centralization of tax collection, and to assess the number of male subjects and build a system of military conscription based on demographic distribution of the entire male population. ${ }^{16}$ At first, due to inexperience, registration was repeated twice, and sometimes three times in certain areas, so that information required by the central bureaucracy was as complete and comprehensive as possible. Kruševo was among these places, as registration was carried out in 1841, 1844, and 1846, the last one being the most comprehensive. ${ }^{17}$

\footnotetext{
${ }^{11}$ For exemplary works that analyze the connections between migration and rural transformation, see Yücel Terzibaşoğlu, "Landlords, Refugees, and Nomads: Struggles for Land around Late-Nineteenth-Century Ayvalik," New Perspectives on Turkey 24 (2001): 51-82; and Meltem Toksöz, Nomads, Migrants and Cotton in the Eastern Mediterranean: The Making of the Adana-Mersin Region, 1850-1908 (Leiden: Brill, 2010).

${ }^{12}$ Aleksandar Matkovski et al., Istorija na Kruševo i Kruševsko: od postanakot na gradot do podelbata na Makedonija, vol. 1 (Kruševo: 1978), 10-12.

${ }^{13}$ This led some chroniclers, and historians like Stoianovich who relied on them, to suggest that the town was founded in 1770 by Vlach immigrants; Stoianovich, "Conquering Balkan Orthodox Merchant," 253.

${ }^{14}$ Matkovski et al., Istorija na Kruševo, 12-14.

${ }^{15}$ For a detailed discussion of these reforms, see Donald Quataert, "The Age of Reforms, 1812-1914," in An Economic and Social History of the Ottoman Empire, 1300-1914, ed. Halil Inalck and Donald Quataert (Cambridge, UK: Cambridge University Press, 1994), 759-94; and Maurus Reinkowski, Die Dinge der Ordnung: Eine vergleichende Untersuchung über die Osmanische Reformpolitik im 19. Jahrhundert (Munich: R. Oldenbourg Verlag, 2005).

Ottoman population registers list only males of all ages within households. Although they are not universal population censuses in the modern sense of the term due to the exclusion of women, they are comprehensive with regard to the male population. Therefore, they can be seen as proto-censuses.

${ }^{16}$ For an overview of Ottoman population registers in this period, see Kemal H. Karpat, Ottoman Population, 1830-1914: Demographic and Social Characteristics (Madison, WI: University of Wisconsin Press, 1985). For failed attempts to introduce conscription see Erik Jan Zürcher, “The Ottoman Conscription System, 1844-1914," International Review of Social History 43, no. 3 (1998): 437-49.

${ }^{17}$ For the registers of these proto-censuses, see BOA, NFS. d. 5473 (1256/1840-41); NFS. d. 5475 (1259/1843-44); and NFS. d. 5483 (1262/1845-46), with given years first Islamic and then Gregorian calendar, and sometimes with exact dates.
} 


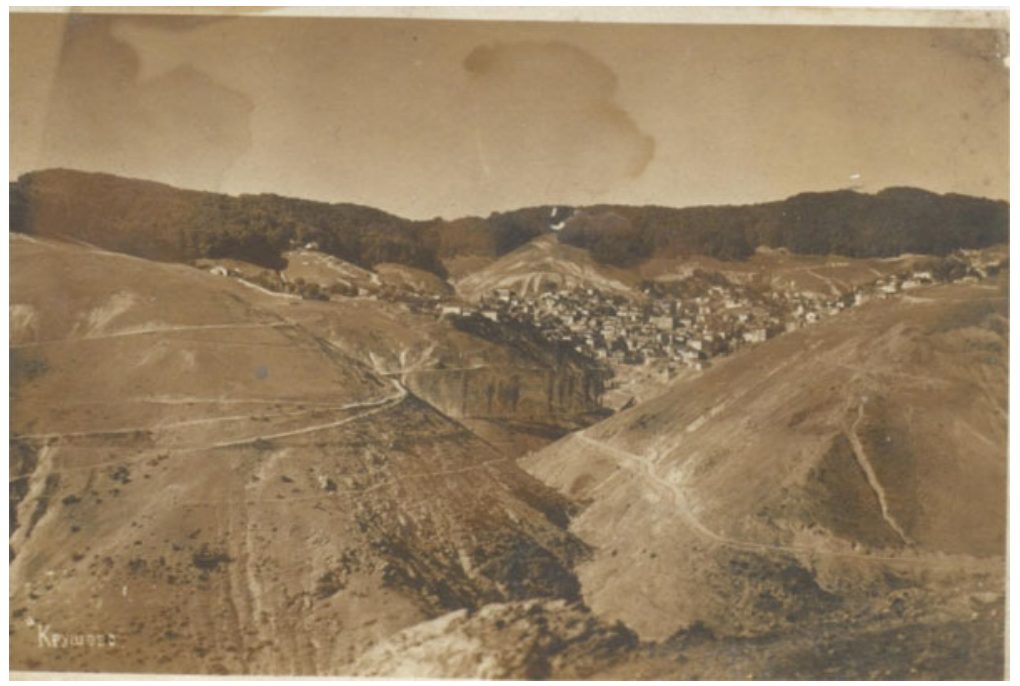

Figure 1. A view of Kruševo in the early 20th century. From BOA, YB.021.114/6, no. 1, 1 January 1912.

The 1846 register was completed and approved by the local council in July 1846, and correspondence with the council assured that all necessary information was collected and "no one was left behind," including those who were absent at the time of the proto-census. ${ }^{18}$ Indeed, this was a critical note for the Kruševo register, as most of the village's population was working outside the village. Of the 3,499 males who were registered in Kruševo, around 52 percent $(1,799$ of 3,499) were recorded as absent, working elsewhere. The ratio of absentees becomes more dramatic when focusing only on subjects who were obliged to pay poll-tax, usually denoting non-Muslim males older than ten or eleven. ${ }^{19}$ In Kruševo, 2,470 males were to pay poll-tax, and around 72.5 percent $(1,790)$ of these were declared to be elsewhere.

The register perfectly captures the occupational diversity of the village population with records of occupational profiles. Among the laborers declared working abroad, 1,656 males were registered with an occupation. Of people recorded to be elsewhere, almost one-third (30\%) were joiners, who most likely worked in the construction sector. ${ }^{20}$ The second largest occupational group was tailors, or 22 percent of the emigrants. Goldsmiths and shepherds constituted 10 and 9 percent of migrants respectively. These four occupations were followed by muleteers, ironsmiths, tinsmiths, butchers, and day laborers. In total, the emigrants were registered in thirty-five different occupations (Fig. 2).

Top occupational groups among the emigrants also were among the highest within the residential population, or people who were present in Kruševo at this time. Of the 1,700 male residents, the register provides the occupations of 526 people, distributed in fifty different occupations. The largest group was the tailors, totaling 140. This was followed by joiners (65), ironsmiths (49), goldsmiths (31), and grocers (22).

Occupational concentration of the Kruševo population in nonagricultural sectors, although striking, was not unusual when it comes to mountainous communities. As the Ottoman authorities acknowledged, Kruševo was a rocky barren place (sengistan), which forced its residents to migrate to earn their livelihoods. ${ }^{21}$ Indeed, Kruševo demonstrated similar patterns to other highland villages with large populations

\footnotetext{
${ }^{18}$ BOA, NFS. d. 5483 (27 B 1262/21 July 1846).

${ }^{19}$ The non-Muslim poll-tax was levied only on economically active male subjects. This tax is a good indicator for the total male non-Muslim taxable populace in the Ottoman Empire. In locations with mixed religious affiliations, the poll-tax loses its explanatory character as Muslims are not included. Nevertheless, as Kruševo did not have any Muslims, in addition to the population registers the poll-tax is a source for comprehensive information on the demography of economically active males.

${ }^{20}$ Dülger is the Ottoman occupational descriptor registrars used, which is a generic term for workers employed in the construction of wooden buildings.

${ }^{21}$ BOA, MLV. 898/68 (9 Ş 1275/14 March 1859).
} 


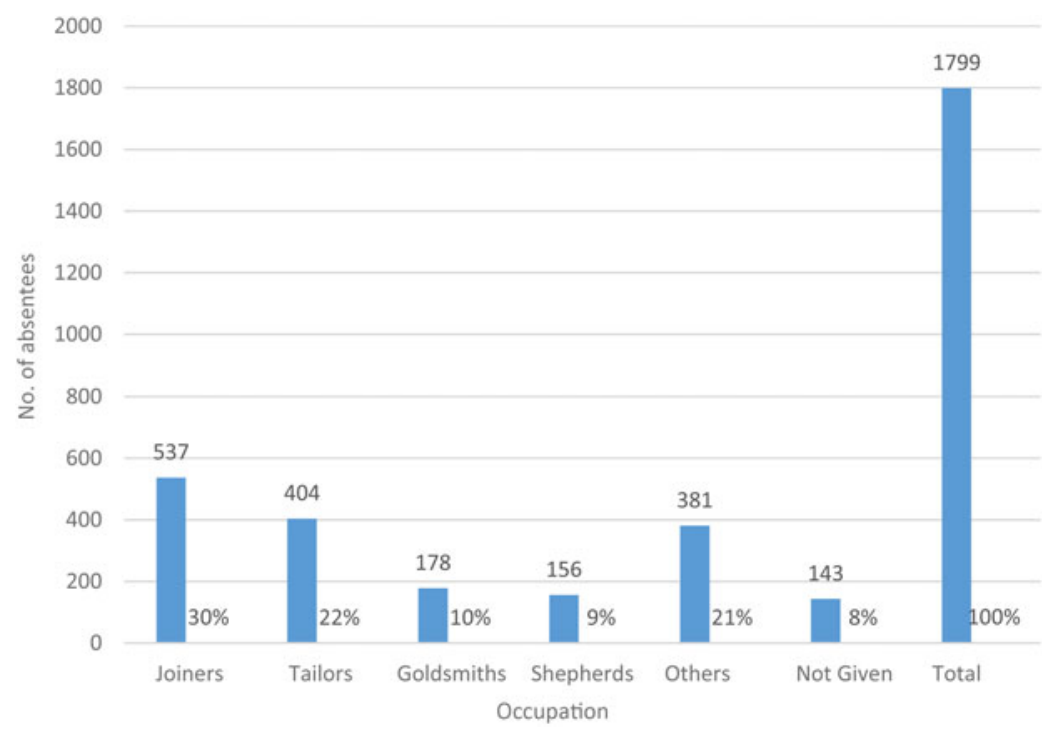

Figure 2. Occupational distribution of male absentees in Kruševo, 1846. Based on BOA, NFS. d. 5483.

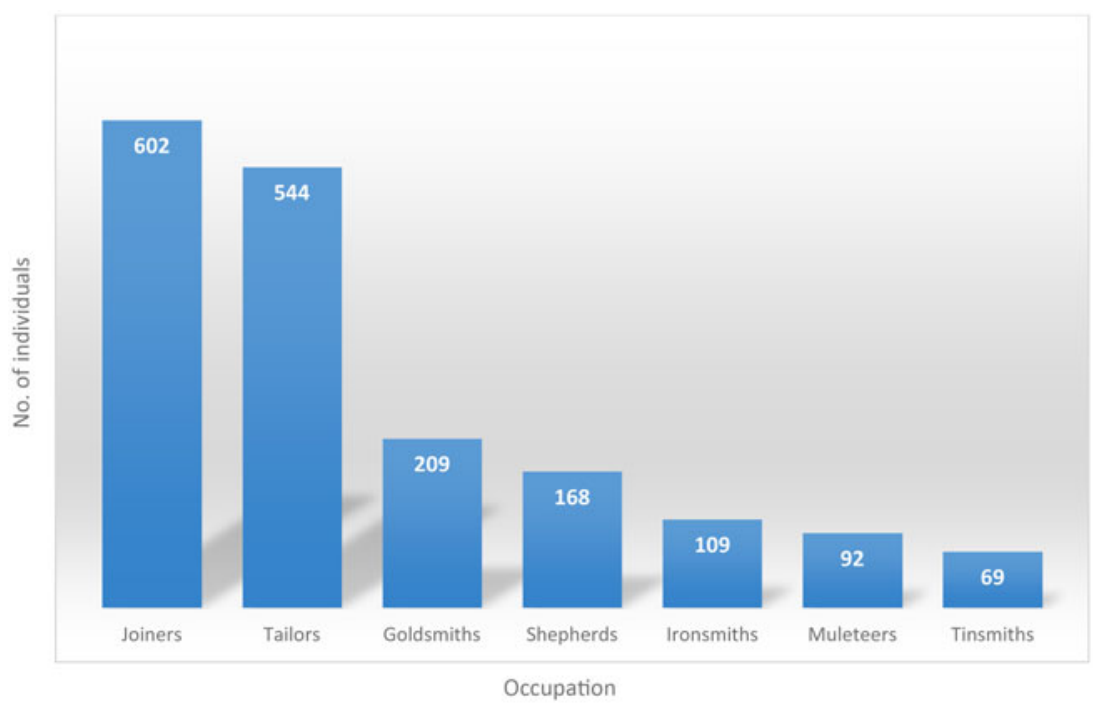

Figure 3. Major occupational groups registered in Kruševo, 1846. Based on BOA, NFS. d. 5483.

involved in activities such as manufacturing, animal husbandry, and male labor migration. ${ }^{22}$ According to Stoianovich, people in the Balkan highlands specialized in specific occupations to sustain their livelihoods: "The men were herdsmen, brigands, seasonal migratory workers, mercenary soldiers, and muleteers, while the women were skilled weavers." ${ }^{23}$ Kruševo followed this pattern; occupations related to manufacturing and animal husbandry were common among both the residents and the migrants (Fig. 3). In the absence of agricultural production, the majority of people were employed in manufacturing (including construction) and animal breeding, which helped sustain a mountainous town with a large population in the 19th century.

\footnotetext{
${ }^{22}$ Ulf Brunnbauer, "Environment, Markets, and the State: Human Adaptation in the Balkan Mountains, 19th-Early 20th Centuries," Ethnologia Balkanica 8 (2004): 129-54, 140.

${ }^{23}$ Stoianovich, "Conquering Balkan Orthodox Merchant," 276.
} 
As described, the overwhelming majority of the population belonged to occupational groups in manufacturing and construction. Sectoral coding and distribution of these occupations suggests that almost 80 percent of the total population in Kruševo belonged to the secondary sector (manufacturing), mainly working as joiners, tailors, goldsmiths, and ironsmiths. ${ }^{24}$ The absence or low level of agricultural production of course played a role in the popularity of nonagricultural sectors, but it does not fully explain why certain crafts were more concentrated than others, especially as these crafts required specific artisanal skills and experience. This leads us to consider the other major feature of life in Kruševo, that is, labor migration. By analyzing why and how people migrated from Kruševo, we can understand not only the concentration of people in certain secondary crafts among both residents and absentees, but also how migration largely determined various parts of both individual and collective life in a rural community.

\section{Labor Mobility and Networks}

Popular perceptions of highland communities may find the case of Kruševo an anomaly, since such communities are primarily seen from a perspective that puts urbanization at the forefront of modern history, considering rural areas economically marginal, demographically in decline, and culturally conservative or even "backward," lagging behind in achievements of modernization. ${ }^{25}$ However, anthropological research on these communities has largely contested this view, emphasizing that the lives of people in these regions have been shaped not merely by their responses to ecological and geographical constraints that limited agricultural production, but also by the ways they have adapted to the larger economic and political contexts in which they lived. ${ }^{26}$ To analyze and understand how people in such communities engaged with and adapted to these larger contexts, we need to concentrate on the nonagricultural economic activities that characterized these strategies. In Southeastern Europe, one of the most significant strategies was labor migration. ${ }^{27}$

As Hahn described in his travelogue, Kruševo lived off the wealth created by urban craftsmen who worked outside Kruševo, in different parts of the empire. ${ }^{28}$ This township, with a majority of people employed in skilled crafts, particularly as joiners, tailors, and goldsmiths, exemplified the phenomenon of pečalbarstvo, which refers to the temporary nature of work and settlement at the place of migration, with maintenance of connections to hometowns and often with families remaining in these towns. The high ratio of absentees in the register proves these connections, as the registrars recorded these absentees to the Kruševo register, most likely in reference to the remaining family members and properties in the village.

If we examine this record together with other records of the same period, we see that the 1846 register gives us only a snapshot of certain patterns and dynamics that defined the pečalbarstvo experience in the mid-19th century. The case of Kruševo provides a perfect opportunity to study this phenomenon, since it stands out as a distinctive source of labor migrants in Ottoman Macedonia, as confirmed by a poll-tax register of 1843. This register listed the absentees of the Bitola district, which included the city of Bitola and the surrounding 118 villages, including Kruševo, who paid their taxes, wherever they were at the time of tax collection. The data in this register suggest that Kruševo had the highest rate of labor migration in the district of Bitola. Of the 2,671 migrant laborers in the district, 578 were from the city of Bitola (22\%) and 1,174 were from all villages other than Kruševo (44\%), whereas a total of 919 (34\%) were exclusively from the village of Kruševo. ${ }^{29}$

\footnotetext{
${ }^{24}$ We used the PST occupational coding system devised by E. A. Wrigley and further developed by Leigh Shaw-Taylor, found at https://www.campop.geog.cam.ac.uk/research/occupations/datasets/coding (accessed 12 December 2019).

${ }^{25}$ For a recent discussion of historical understanding of mountains and mountaineers see Bernard Debarbieux and Gilles Rudaz, The Mountain: A Political History from the Enlightenment to the Present, trans. Jane Marie Todd (Chicago: University of Chicago Press, 2015), particularly ch. 3.

${ }^{26}$ As Brunnbauer noted, "we must not a priori view mountain communities as isolated, closed social systems, but rather in each case, we have to empirically assess the intensity of their integration within larger social, economic and cultural frameworks" (“Environment," 133).

${ }^{27}$ Brunnbauer, "Environment," 140.

${ }^{28} \mathrm{Hahn}$, Reise von Belgrad nach Salonik, 180.

${ }^{29}$ BOA, ML.CRD.d. 746 (1259/1843-44).
} 


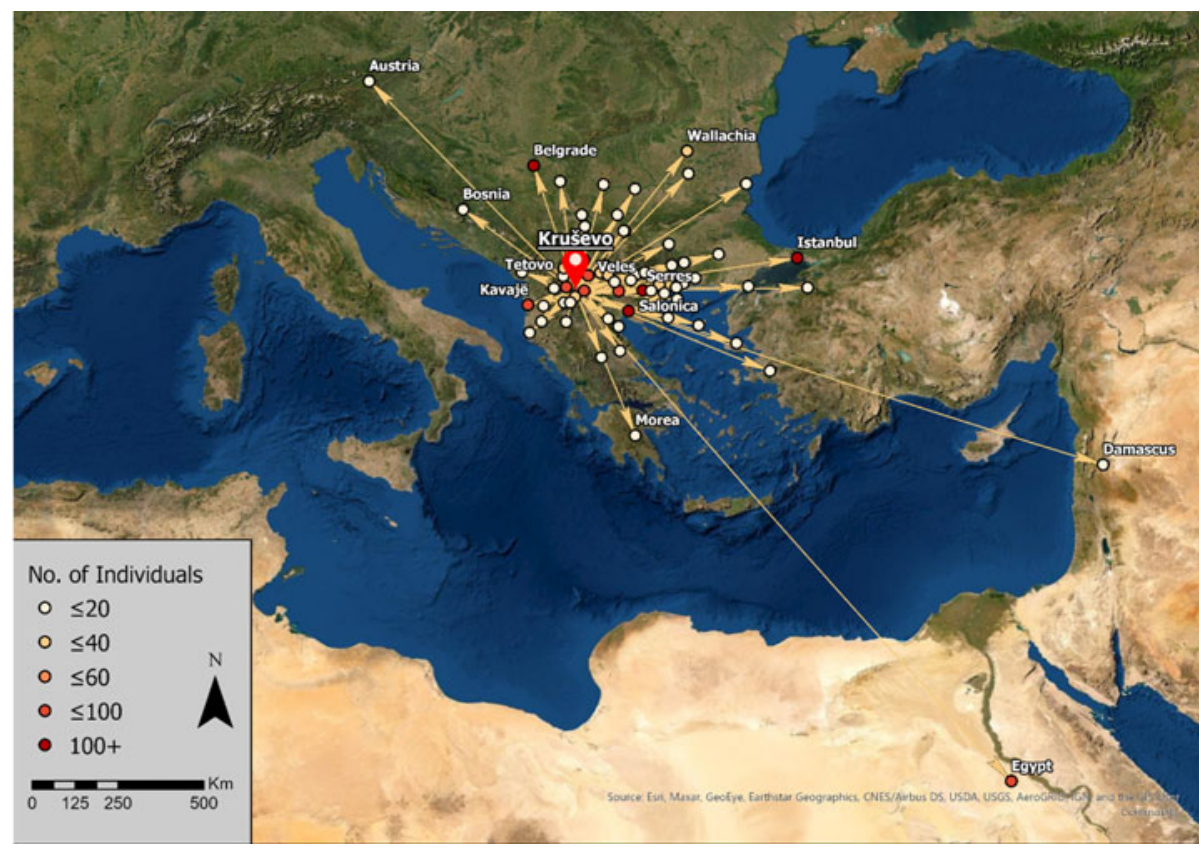

Figure 4. Major destinations of labor migration from Kruševo, 1846. Based on BOA, NFS. d. 5483.

A closer look at the 1846 register suggests that absentee males worked in 75 different locations. Although many went to nearby regions in the Balkans, there also were a considerable number outside the Balkans, including Istanbul (143), Izmir (9), Thasos (8), Damascus (10) and Egypt (99). Around half of the immigrants (817 out of 1,799) left for five places: Belgrade, Salonica, Istanbul, Serres (Siroz), and Egypt. Most of them went to big urban centers of the time, which were in need of manpower and where migrants had more chances of employment in nonagricultural sectors (Fig. 4).

The occupational data of these labor migrants also suggest that there is a direct relationship between the occupational profile and the place of migration, and that individuals from the same occupational groups concentrated in specific cities. Of the 236 people who were in Belgrade, at least 130 were registered as joiners and 43 as tailors. In Salonica, among the 210 people, 92 were joiners, followed by 43 tailors, 20 muleteers, 14 tinsmiths, and 12 shepherds. In Istanbul again joiners (43) and tailors (33) were dominant, in addition to 33 butchers. Egypt and Serres present a more striking case: of the 99 people who left for Egypt, 85 were tailors, whereas among the 129 people who were in Serres, 91 were joiners. On the other hand, in Kavaje and Veles the shepherds dominated the other occupational groups, constituting 77 percent and 60 percent of the total number of migrants, respectively.

Balkan historians have known that craftsmen of mountainous regions, especially in and around Ottoman Macedonia, had "a tradition of temporary labor migration lasting from a few months to a few years." ${ }^{30}$ This conclusion seems to be confirmed by the registers, although with some nuances. Thanks to the poll-tax register of 1843 , it is possible to document the patterns of seasonality and temporality among the labor migrants from Kruševo. A typical entry in this document provides not only the name, age, and poll-tax level of the absentee (low, medium, or high), but also the number of years during which he had been working in the place where his poll-tax was collected. This record lists the place of work and duration of stay of 2,664 migrants registered in the Bitola district. The minimum duration was one and a half years at the same place. Of these migrants 64 percent were registered as staying three years or more, for as long as eight years. At least in this regard, Kruševo seems to have followed the same pattern as other districts in the region: like the rest of the villages and the city of Bitola, the

\footnotetext{
${ }^{30}$ Hristov, "Balkan Gurbet," 36-37.
} 
overwhelming majority of migrants from Kruševo (93\%) stayed between one and a half and four years, the rest staying much longer, for five to eight years at the same place. ${ }^{31}$

This does not necessarily mean that migration was a one-time or one-way experience for the migrants. Indeed, there is considerable evidence regarding the mobility of the migrants across different destinations. This was determined by matching the individuals listed in both the 1843 poll-tax register and the 1846 population register and then comparing the data about the same individuals from both registers. In this way, we were able to match 567 people who were registered to work elsewhere during this period. A comparison of the data suggests that more than one-third of these people (204 out of 567) moved to another location between 1843 and 1846. More than half of these wandering migrants were tailors (63) and joiners (63), which suggests a direct connection between the type of work and its duration.

One can assume that these migrants largely belonged to occupational groups who did not need to keep a shop or possess capital to carry out their trades, and thus were free to move whenever they found a (better) job elsewhere. This seems to have been the case for itinerant joiners, who moved from one construction project to the next, as well as tailors and some other itinerant groups such as shepherds (13), tinsmiths (13), and muleteers (8). ${ }^{32}$ However, it also is true that shopkeepers were not exclusively static, considering a remarkable number of goldsmiths (19) as well as 6 ironsmiths, a grocer, an innkeeper, and a tavern-keeper who changed their places of work in this period. Still, it is undeniable from these figures that being dependent on shopkeeping restricted the experience of migration to a specific location for a longer period.

\section{Maintaining Connections to the Hometown}

It is difficult to be sure whether migrant laborers settled down in these locations or came back to Kruševo on certain occasions, as population and tax registers only give us snapshots of the specific time of registration. Studies on labor migration in the Balkans highlight the seasonal and/or temporary movement of these workers, although the amount of time they stayed away from their villages seems to have varied. Hristov points out the seasonal character of the mobility of craftsmen in mountainous villages, particularly construction workers in Bulgaria, who usually "travelled from early spring to late autumn throughout the Balkans." 33 Palairet, on the other hand, cites "the Kruševo gurbet" as an example of the mobility of Cincars (Aromanians) who were known to have specialized in sheep breeding, and who became small businessmen, opening their own shops and staying away from their villages for as long as thirty years. ${ }^{34}$ The absence of agricultural lands in Kruševo, which would have forced these migrants to return to their villages more often, suggests that migrants from Kruševo stayed away for much longer periods, something that also was highlighted by Palairet on the basis of his analysis of Galičnik, another highland village in this region. ${ }^{35}$

Still, tracing specific individuals or families through different registers confirms that most of these people remained connected with their hometowns, even for decades. For instance, Nikola, son of Yolo, head of a household with four male members, was a tailor working in Egypt in 1843; according to the 1840 register he had already been working there for six years. The household remained there in 1846 . In other words, Nikola seems to have been away from his hometown for at least twelve years, together with a 30 year old son and a nephew who later joined them. However, another son of Nikola was residing in

\footnotetext{
${ }^{31}$ BOA, ML. CRD.d. 746 (1259/1843-44).

${ }^{32}$ For a micro-historical analysis of a legal case about a carpenter (working in construction) from Bitola, who moved first to work in shipbuilding in Istanbul and then to different Aegean towns and villages to work in the construction of houses and mansions, see Omri Paz, "The Usual Suspect: Worker Migration and Law Enforcement in Mid-Nineteenth-Century Anatolia," Continuity and Change 30 (2015): 223-49.

${ }^{33}$ Hristov, "Balkan Gurbet," 38.

${ }^{34}$ Palairet, "Migrant Workers," 32.

${ }^{35}$ There is an astonishing and complete absence of agricultural land registered to Kruševo inhabitants in temettuat registers in the 1840s. For UrbanOccupationsOETR we have been examining entire temettuat registers of four locations in the Bitola region: the towns of Bitola (ML.VRD.TMT.d. 11444), Florina (KK.d. 6078), Prilep (ML.VRD.TMT.d. 11447), and Kruševo (KK.d. 6079). Whereas in total 415 households registered 496 units of agricultural production in the town of Bitola, 571 households registered 1,050 units in the town of Florina, and 611 households registered 834 units in Prilep, in Kruševo only 1 household among a total of 916 registered one small garden of half an Ottoman dönüm $(0.1$ acres).

For Galičnik see Palairet, "Migrant Workers," 45.
} 
Kruševo by 1846. He was ten years old, suggesting that Nikola had probably returned home two years following his initial departure. ${ }^{36}$ If we rely on these registers, his second return seems to have been at least four years later, because the 1843 register notes that he had been in Egypt for two years.

This case points to another important factor that was crucial to migrants maintaining connections with their hometowns and connections to each other in the place of destination, that is, formation of family and neighborhood networks in a specific destination. It is evident that kinship was a significant component of chain migration networks, as a considerable number of migrants followed other members of their households. According to the 1846 register, of the 236 migrants from Kruševo who were in Belgrade and the 210 in Salonica, 138 migrants in each location were accompanied by at least one individual from the same household, and each of these cities had 19 households who had three or more members. Of the 57 households who sent 99 people to Egypt, 22 sent at least two members, and 12 sent at least three. There were two families with five members and one with six members. Neighborhood relations seem to have played a similar role, according to the register. Almost two-thirds of the 73 people who left for Kavaje, for instance, were registered to two neighborhoods in Kruševo. Of the 210 people who were in Salonica, almost half of them (98 people) were residents of three neighborhoods, whereas in Serres, again around half of the immigrants belonged to two neighborhoods in Kruševo.

It seems very likely that the occupational trajectories of individuals were largely determined by such relations. In Salonica, 14 of the 19 households who had at least three members were involved exclusively in a single craft. There were 13 of 19 such households in Belgrade, and 10 of 12 in Egypt. People seem to have followed their family members or neighbors to a specific destination, most likely before they acquired a specific craft. Indeed, among the absentees there were 46 individuals who were registered as apprentices and 4 as journeymen. Similar to the migration patterns of occupational groups, the overwhelming majority of these apprentices and journeymen were joiners (24) and tailors (18), followed by goldsmiths (4), tinsmiths (2), and ironsmiths (2). As there were only seven apprentices among those present in Kruševo, four of whom were tailors, we suggest that several young emigrants acquired their skills and experience in specific crafts in the place to which they migrated, rather than in Kruševo, highlighting the importance of migration and skill networks.

Even when individuals migrated with most of their family members for a long period, it did not necessarily end their connection to Kruševo, as often family members remained behind, most often women and younger children. One example was the family of 35 year old Teohari, son of Nikola, from the neighborhood of Papa Isteryo. Teohari had no sons recorded in the register, but four brothers $(32,28,25$, and 22 years old). All five brothers had been in Egypt for at least four years in 1846, working as tailors. ${ }^{37}$ Although all male members of the family were in Egypt, the remaining female members appear to have remained in Kruševo. According to a tax register from the same period, the average annual revenue of the whole family was 2,750 kuruş, and they paid 104 kuruş in income tax. No other income-yielding assets were mentioned in the register. The family seems to have depended entirely on remittances from the five brothers in Egypt. ${ }^{38}$ Leaving family members behind and therefore retaining their property in Kruševo probably explains why they were still registered in Kruševo tax and population registers. It is also the reason many of them continued to live in bachelor inns, no matter how long they had been living in the same place. $^{39}$ Istefo, son of Kiro, who came to Tetovo (Kalkandelen) in about 1831 continued to live in an inn, called Topalzade Hanı, until around 1848, although he had worked there as a goldsmith for this entire period and had brought his two sons there, who also were goldsmiths. In 1848, however, Istefo and one of his sons seem to have returned to their hometown, as they were recorded to be present in Kruševo. ${ }^{40}$

Maintaining connections to their hometowns likely helped migrants survive the challenges of living in a different city: they formed friendships and solidarity with their fellow migrants from Kruševo. This

\footnotetext{
${ }^{36}$ BOA, ML.CRD.d. 746; NFS. d. 5483 (27 B 1262/21 July 1846); and ML.VRD.CMH.d. 20.

${ }^{37}$ BOA, NFS. d. 5483 (27 B 1262/21 July 1846), fl. 74.

${ }^{38}$ BOA, KK.d. 6079 (1261/1845), fl. 581.

${ }^{39}$ Bachelors in this sense should be understood not necessarily as unmarried males but as males without their female family members. For a study of itinerant labor migrants living in bachelor inns in Istanbul, see Florian Riedler, "Wanderarbeiter (Bekar) im Istanbul des 19. Jahrhunderts: Zwischen Marginalität und Normalität," in Bettler, Prostituierte, Paria: Randgruppen in asiatischen Gesellschaften, ed. Anja Pistor-Hatam and Antje Richter (Hamburg: EB Verlag, 2008), 143-58.

${ }^{40}$ See BOA, ML.CMH.d. 766 (1263/1847), fl. 43; BOA, NFS. d. 5576 (1263/1847), fl. 7; and BOA, NFS. d. 5483, fl. 124.
} 
helped them maintain their identities and created a sense of belonging. Thus, during a police investigation for a burglary in his shop in Dupnica, a goldsmith declared his hometown as Kruševo, although he had been living in Dupnica for almost thirty years and said he had recruited a 12 year old relative from Kruševo as his apprentice recently. ${ }^{41}$ This was the case for other itinerant occupational groups as well, such as the tailors in Salonica who organized to form a guild with their fellow countrymen from Kruševo, rather than with their Salonican counterparts; this would in turn make them a part of the ethno-religious confrontation between the Vlach and Greek churches in the early 20th century. ${ }^{42}$

This double sense of belonging, that is, claiming a permanent relationship to the destination of migration without cutting relations with the hometown, gave migrants some leverage with local authorities, which they continued to manipulate until at least the early 20th century. Some migrants who continued to have family members or properties in Kruševo despite having left their hometown decades ago demanded exemption from local taxes because of their longtime residence in a different place. For instance, the Nishkov brothers, who had settled in Bulgaria twenty years earlier, petitioned in the 1870 s to be removed from the registers of Kruševo. They did not want to pay their local taxes, as they no longer claimed any connection to Kruševo. However, the Ottoman authorities denied this claim and argued that the brothers maintained connections since they still had family and estates in their original town, and so were required to pay their taxes. ${ }^{43}$ In other cases it was the Kruševo connection that the migrants claimed to ease their situations, for exemption from obligations in the place of destination. This was the case with the migrants who worked in post-1878 Bulgaria, which became de facto independent. When they were called to join the Bulgarian army, many from Kruševo applied to the Ottoman Foreign Ministry for proof of their subjecthood because of their lasting connections to their hometowns, which were still in Ottoman territory, so that they could be exempted from military service. ${ }^{44}$

\section{Migration and Socioeconomic Transformation in Kruševo}

It is not surprising that such large-scale migration had considerable impact on the physical, socioeconomic, and cultural landscape of Kruševo in the 19th century. Indeed, Hahn's description of the village in 1858 is of a dynamic social and economic life. On Monday, Thursday, and Saturday evenings each week bazaars were organized, attracting people from nearby villages as well. There were thirty-two inns for visitors, pointing to a high frequency of mobility outside and around the village. Ten ironsmiths were producing nails and other ironware, crafting iron transported from Samokov and Salonica. Eight tallow shops (Talgsiederei) were producing for markets in Istanbul, Salonica, Skopje, and Bitola. Merchants of Kruševo had networks with all trade centers in the Levant, and in Vienna alone there were six commercial houses owned by these merchants, according to Hahn. ${ }^{45}$ His observations are confirmed by an Ottoman document of the previous decade. ${ }^{46}$ In short, in spite of being a mountainous community, Kruševo was highly integrated with the local and regional markets of the Ottoman Empire and Europe.

This economic wealth was accompanied by ethnic heterogeneity, a direct outcome of migration and the profile of immigrants in the village. According to local accounts based on literary or oral sources, Vlachs of the village migrated from the Vlach towns that were raided and destroyed in the late 18th century. Many of these migrants were from Moscopole, which by that time was one of the most important economic and cultural centers of the Balkans, with high levels of education (as signified by a printing press and schools) and migrant labor, the networks of which might be inherited by their descendants in Kruševo. Most of the merchant and artisan families belonged to this community. The Mijak wave of migration in the early 19th century brought a significant number of Bulgarian-speaking people to Kruševo, among whom joiners were a majority. Other waves from Albania also brought a significant number of Christian Albanians, many of whom, together with nomadic Vlachs, specialized in cattle and related trades. ${ }^{47}$ Until the last quarter of

\footnotetext{
${ }^{41}$ BOA, MVL. 1081 (17 L 1282/4 March 1866).

${ }^{42}$ BOA, BEO. 2950-221224 (11 L 1324/28 November 1906).

${ }^{43}$ BOA, DH.MKT. 2217/80 (19 Haziran 1325/1 July 1899).

${ }^{44}$ For exemplary cases, see BOA, HRS.SFR.04. 409/31 (19 April 1898) and 431/40 (1 March 1900).

${ }^{45}$ Hahn, Reise von Belgrad nach Salonik, 180-81.

${ }^{46}$ BOA, İ. MVL. 53/1015, nos. 2 and 3 (8 Şaban 1259/3 September 1843).

${ }^{47}$ Matkovski et al., Istorija na Kruševo, 18-23.
} 
Figure 5. Kruševo in the early 20th century. From BOA, YB.021.114/6, no. 3, 1 January 1912.

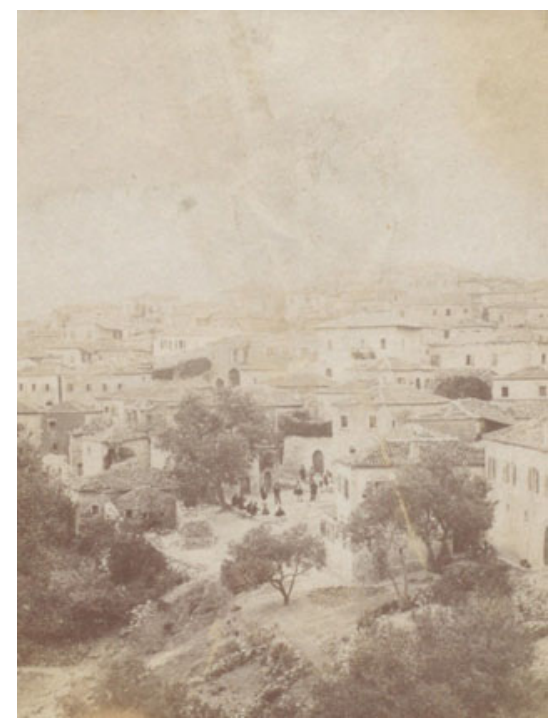

the 19th century, marked by the struggles of the Bulgarian and Vlach communities to secede from the Greek Church, this ethnic diversity did not lead to any serious confrontation, although, as mentioned by Hahn, there were some problems between Albanians and Bulgarians about animals. ${ }^{48}$

This socioeconomic profile, reflected in an expansive trade activity and a high level of money circulation due to remittances sent by migrants, seems to have translated into a remarkable level of capital accumulation within the town, especially through the mid-19th century. The changing landscape of the village during the 19th century confirms this. As migration waves began in the late 18th century, the village, originally located on the left side of the Kruševo River, expanded to the right side. ${ }^{49}$ The village became urbanized, with the construction of fine stone houses, churches, coffee houses, artisanal workshops, and schools. ${ }^{50}$ The newly emerging merchant and artisan community played a considerable role in this spatial transformation, marked by the emergence of a town center around a marketplace, the construction of a Greek Orthodox Cathedral, St. Nicholas (which became famous in the Balkan world particularly for its iconostasis), the houses of some merchant families, especially the Nitsota family, and the establishment of a modern school in 1847 on land granted by a merchant who worked in Serres (Fig. 5). ${ }^{51}$ Perhaps it was this prosperity and the socioeconomic power of the community that whetted the appetite of some local Muslim dignitaries from Bitola who attempted to exploit this wealth by claiming the ownership of all property in the village. However, this affluence also made the community's voice heard by the central bureaucracy in the first half of the 19th century.

With increasing integration of this mountain village with regional and trans-imperial markets, socioeconomic struggles between local power holders and the villagers intensified. Meanwhile, the Ottoman central bureaucracy launched a series of reforms meant to restructure the Ottoman state and society in line with

\footnotetext{
${ }^{48} \mathrm{Hahn}$, Reise von Belgrad nach Salonik, 182. It is important to emphasize that these accounts did not dwell on well-defined and fixed definitions when they mentioned people's ethnic affiliations, and they should be approached cautiously. Official Ottoman registers in the mid-19th century did not differentiate the population by ethnicity, and all Christians affiliated with the Greek Orthodox Church were officially defined as Greeks.

${ }^{49}$ Matkovski et al., Istorija na Kruševo, 11.

${ }^{50}$ Matkovski et al., Istorija na Kruševo, 14.

${ }^{51}$ The works of the carvers from Kruševo were famous all over the Balkans, especially those of Dimitar and Andon Stanišev, who worked on the iconostasis of the St. Nicholas cathedral. Dimitar was the son-in-law of one the most legendary carvers in the Balkans, Petar Filipovič, who died in Kruševo in 1854. See Dimitar Ḱornakov, Blagoja Drnkov, and Nada Saratinovska, Macedonian Wood-Carving (Skopje: Misla, 1994), 22-24. According to the Ottoman proto-census of 1846 (BOA, NFS. d. 5483), brothers Dimitar and Andon were working in Belgrade as joiners (dülger).

For other construction and the school, see Matkovski et al., Istorija na Kruševo, 65; and Keith Brown, The Past in Question: Modern Macedonia and the Uncertainties of Nation (Princeton, NJ: Princeton University Press, 2003), 86.
} 
European norms and ideas, beginning in the late 1830s. The Tanzimat process promised to side with the non-Muslim villagers, against the oppressive Muslim power holders in the Balkans, especially by means of laws that guaranteed the protection of property. This opened a legal space for the people in Kruševo to free themselves from the yoke of the local dignitaries, acting on the promises of the Tanzimat elites to protect their subjects, regardless of their religion, against the illegal practices of the local elites.

As confirmed by an imperial decree on 15 November 1804, Kruševo was attached to imperial private properties to be leased as lifetime tax-farming. In other words, the land belonged to the state and could not be converted to private ownership. ${ }^{52}$ According to the Ottoman records, the concession for lifetime tax collection belonged to a notable provincial family, the Mustafapassazades, beginning in the late 18th century. ${ }^{53}$ When the increasing immigration and remittances from emigrants led to the prosperity of the village, as marked by the construction of new residential houses and shops, local power holders used the opportunity to exploit this development. They claimed the territory as their property (çiftlik), which enabled them to claim ownership of the new construction and demand rents from these houses, fields, and shops. The local elites wanted to transfer the wealth resulting from migration into personal financial gains.

Although early attempts by the Mustafapaşazades were stopped by the governors, in the 1830s their descendants, led by Abdülkerim Bey and more than a dozen "shareholders," with the support of a new governor on their side, were able to collect rents from the population. Abdülkerim and other shareholders collected high rents, claiming these estates as private property inherited from their ancestors. They also were able to obtain a local court decision ruling that the village was their çiftlik, although this practice of establishing çiftliks in villages with a local court decision was strictly prohibited by the imperial center. Therefore, the people in Kruševo collectively decided to take the matter to Istanbul. ${ }^{54}$

Initially it seems they failed, as an 1836 imperial decree vaguely implied the legitimacy of charging household rents, based on some records in the treasury. However, the claim that the territory was the çiftlik or private property of the shareholders was absolutely rejected and the case returned to the local court. ${ }^{55}$ Despite this decree, the people of Kruševo continued the legal struggle and refused to pay rents to the landlords for the next six years. They were more fortunate this time, as the reformist Tanzimat bureaucracy was more sympathetic to the cases of non-Muslims against Muslim landlords in the Balkans. ${ }^{56}$ A new edict, in 1842, based on a long and well-argued report by the newly established Supreme Council for Judicial Regulations (Meclis-i Vala), ruled on behalf of the people of Kruševo, absolutely repudiating not only the 1836 edict (on the basis of discursive contradictions within the text), but also the entire claim of ownership by the aforementioned claimants. ${ }^{57}$ Nevertheless, immediately after this edict, apparently under pressure from local councils in the Ottoman Balkans (which were dominated by local landlords as well as the local bureaucracy), the Supreme Council decided that this rule might lead to unintended consequences if villagers in many other çiftliks throughout the Balkans acted on this decision against the landlords and claimed ownership of properties.

\footnotetext{
${ }^{52}$ Property relations and their transformation in the 19th-century Ottoman Empire are highly debated topics. For an authoritative review of the literature, see Huri Islamoglu, "Property As a Contested Domain: A Reevaluation of the Ottoman Land Code of 1858," in New Perspectives on Property and Land in the Middle East, ed. Roger Owen and Martin P. Bunton (Cambridge, MA: Harvard University Press, 2000), 3-61.

${ }^{53}$ The Mustafapaşazade family was among the prominent Muslim landed gentry of 19th-century Bitola, together with the Zaimzades, Selimağazades, and Yahyabeyzades. Through their local power, these families also secured the highest provincial posts of the districts. For a general review of the leading çiftlik-holders of the Bitola region, see Michael Ursinus, "The 'Çiftlik Sahibleri' of Manastır as a Local Elite, Late Seventeenth to Early Nineteenth Century," in Provincial Elites in the Ottoman Empire, Halcyon Days in Crete V (10-12 January 2003), ed. Antonis Anastasopoulos (Rethymno, Crete: Crete University Press, 2005), 247-57. See also Aysel Yıldız and İrfan Kokdaş, "Peasantry in a Well-Protected Domain: Wallachian Peasantry and Muslim Çiftlik/Kışlaks under the Ottoman Rule," Journal of Balkan and Near Eastern Studies 22, no. 1 (2020): 175-90.

${ }^{54}$ The annual charge in the 1830s was 16,000 kuruş for each household. See BOA, İ. MVL. 53/1015 (undated). See also BOA, İ. MVL. 53/1015 (undated).

${ }^{55}$ BOA, İ. MVL. 35-634, no. 3-4.

${ }^{56}$ For a specific reference to the newly introduced Tanzimat reforms in the dispatches concerning the problems in Kruševo, see BOA, İ. MVL. 34/586 (22 N 1257/7 November 1841), nos. 3-1 and 2.

${ }^{57}$ BOA, İ. MVL. 35-634-6; BOA, İ. MVL. 35-634-7.
} 
To solve this dilemma in a way that would be acceptable to the state, the landlords, and the villagers, a mediator (the former judge of Jerusalem) was sent to the district. ${ }^{58}$ As a result, a new deal was reached, according to which the villagers accepted the claim of ownership by the landlords, and the landlords agreed to sell these properties to the villagers. On 19 August 1843, the houses, the adjacent lands, as well as shops and inns were transferred to the villagers of Kruševo in return for 250,000 kuruş. The sale included not only the 1,385 houses, 113 shops, 8 inns, and 5 slaughterhouses present at the time, but also the entire territory of the village, protecting the village from any future claims by the landlords. ${ }^{59}$ Although it came with a cost, the people of Kruševo were able to free themselves and their property from the local landlords for good.

It is remarkable that a highland community in the Balkans could wage a years-long legal struggle in the imperial capital against a number of notable local families that were backed by the local courts and bureaucracy. The existence of a diaspora in Istanbul was an obvious advantage, as the village was represented by these immigrants against the landlords before the Supreme Council for Judicial Regulations, and, as demonstrated by the case documents, these Kruševo migrants in Istanbul could keep the bureaucracy under pressure since they could petition the Sultan directly. ${ }^{60}$

In addition to the court case in Istanbul, the importance of these migration networks and the wealth they created are evident in profiles of the representatives during the court cases in Bitola. In the final instance, thirteen representatives of the village went to court and approved the purchase of the village on behalf of their fellow villagers. Each quarter had sent a representative to the court, each of them being a religious or political authority and/or an affluent merchant of the neighborhood. Their profiles confirm that, in addition to political or religious status, capital ownership was an important factor when representing the neighborhood population. Most of the representatives came from families that had not only priests but also merchants, some of whom had connections to distant markets, including the Austro-Hungarian Empire. ${ }^{61}$ The representative of the Büyük Papa Dimitri neighborhood was Tomo, son of Dimitri, who was an Austrian merchant with his brother; both belonged to a priest's family. Another representative, from the Çoço quarter, also was a priest, whose brothers were goldsmiths in Dojran and in Skopje. The increasing economic power of the village population, thanks particularly to migration networks and remittances, played an important role in the collective ability of this mountainous non-Muslim community to successfully obtain their rights when contesting the traditional Muslim elites at the imperial center in Istanbul.

\section{Conclusion}

In this article, thanks to the newly available population and tax records of the Ottoman archives, we have demonstrated how labor migration and migration networks could transform a geographically distant mountainous community and include it in the larger transformation processes of the 19th century. By documenting specific details about the movement of people between Kruševo and the rest of the empire, we see how these migration patterns and networks created a socioeconomically diverse community that maintained these networks over long decades and used them to take their own part in the socioeconomic and political modernization processes that marked the mid-19th-century Ottoman Empire. Indeed, as this article shows, the people of Kruševo illustrate that geographical distance and the absence of agricultural production did not necessarily hinder social change, even in a highland village. Only by means of a focus on nonagricultural activities, including labor migration, is it possible to analyze and understand the role these communities played in the imperial and global transformations of the 19th century.

\footnotetext{
${ }^{58}$ BOA, İ. MVL. 50/958, no. 13 (undated).

${ }^{59}$ BOA, İ. MVL. 53/1015, no. 2-3 (8 Ş 1259/3 September 1843).

${ }^{60}$ For a reference to such a petition to the Sultan, see BOA, İ. MVL.50/958, no. 13 (undated). For a discussion of strategies and methods of petitioning in the late Ottoman Empire, see M. Erdem Kabadayl, "Petitioning as Political Action: Petitioning Practices of Workers in Ottoman Factories," in Popular Protest and Political Participation in the Ottoman Empire: Studies in Honor of Suraiya Faroqhi, ed. Eleni Gara, M. Erdem Kabadayl, and Christoph K. Neumann (Istanbul: Bilgi University Press, 2011), 57-74.

${ }^{61}$ BOA, İ. MVL. 55-10.
} 
Migration and mobility continued to contribute to politicization of the residents of Kruševo during what remained of the 19th century. In the age of nationalist movements, the migration networks of people from Kruševo played a critical role in the circulation of ideas and mobilization of people around these ideas. The official secession of the Bulgarian Church from the Greek patriarchate and the emergence of a semi-independent Bulgarian state in the 1870s accelerated this process within Kruševo as well. The intensified construction process, especially in emerging capital cities in the Balkans, like Sofia, drew large numbers of immigrant workers, particularly from Macedonia, who were introduced to new ideas and organizations. The emerging autonomist and nationalist groups were able to mobilize their fellows and circulate their ideas thanks largely to the existence of these migration networks that dated back decades. ${ }^{62}$ It is not surprising that the Bitola district became the bedrock of a constitutional revolution in the Ottoman Empire by July 1908.

Acknowledgments. We are members of the research project, UrbanOccupationsOETR, Industrialisation and Urban Growth from the mid-nineteenth century Ottoman Empire to Contemporary Turkey in a Comparative Perspective, 1850-2000, (urbanoccupations.ku.edu.tr) funded by the European Research Council (ERC) under the European Union's Horizon 2020 research and innovation programme (grant agreement No. 679097) hosted at Koç University. We thank all members of our project team who have contributed to the construction of data sets and to this article in various forms. We are especially thankful to two members: to Kirila Atanasova for translating sources in South Slavic languages into English and making them accessible to us, and to Piet Gerrits for devising the map in Fig. 4.

\footnotetext{
${ }^{62}$ For the significance of labor networks in the formation of revolutionary movements, see Keith Brown, Loyal unto Death: Trust and Terror in Revolutionary Macedonia (Bloomington, IN: Indiana University Press, 2013), particularly ch. 2. As Brown shows, at the turn of the century the increasing tensions and the politicization process in the Balkans would culminate in the 1903 Ilinden Uprising in Kruševo, which had much to do with the modernization process and the migration networks in this region. See also Brown, Past in Question.
}

Cite this article: Sefer A, Yıldız A, Kabadayı ME (2021). Labor Migration from Kruševo: Mobility, Ottoman Transformation, and the Balkan Highlands in the 19th Century. International Journal of Middle East Studies 53, 73-87. https://doi.org/10.1017/ S0020743820000847 